\title{
THE IMPORTANCE OF THE GERMPLASM IN DEVELOPING AGRO-ENERGETIC PROFILE SUGARCANE CULTIVARS
}

\author{
Silvana Creste, Luciana Rossini Pinto, \\ Mauro Alexandre Xavier and Marcos Guimarães de Andrade Landell
}

\section{INTRODUCTION}

Sugarcane improvement programs play an important role in the sugar-alcohol industry, as they are the source for developing varieties, the main technological input for sugar and ethanol production. Over the last three decades, important gains were achieved in agribusiness, mostly resulting from breakthroughs in genetic improvement. Among its objectives, the increase in stalks sugar content was always one of the major goals, as improving such feature reflects an economic interest, as harvesting, transportation, and milling costs remain practically unchanged. However, a new paradigm for energy production is rising based on biomass production: to use the whole plant, dissociated from sugar production.

The energy cane concept proposed by ALBERT-THENET (2003) emphasizes the differentiation of sugarcane varieties with high fiber content from those previously produced to obtain sugar and bagasse, leading to the development of varieties with characteristics favorable to power generation. This particular type of sugarcane foresees high fiber content (25\%), 100 tons/ha.year productivity, $25 \%$ of trash/cane, 12\% Pol\% cane, which would provide around 50 tons of fiber per hectare/year.

One important aspect in the development of high biomass yield sugarcane varieties relates to using energy as a primary function to optimize and select clones and/or varieties. In this context, clones may be selected by their primary energy $\mathrm{PE}$, i.e., megajoule per ton of sugarcane (MJ/tc).
This concept considers the total energy from sugarcane, including fiber, saccharose, and reducing sugars $-\mathrm{RS}$, and is given by the formula: $\mathrm{MJ} / \mathrm{tc}=$ $18 \mathrm{x}$ kg fiber (dry matter) + $16 \mathrm{x} \mathrm{kg}$ saccharose + $15.6 \mathrm{x} \mathrm{kg}$ reducing sugars. This equation may be used to optimize sugarcane cultivars for maximum power generation, i.e., in the selection of the socalled energy cane, as fuel cane should deliver a primary energy of $1,100 \mathrm{MJ} /$ tons of cane per year (LEAL, 2008).

In this new concept, improvement programs will have their focus redirected to developing cultivars compliant to this new varietal profile.

Particularly in Brazil, the growing demand for ethanol fuel, as well as the need to ensure the country's competitiveness in the international trade and its leadership in bioenergy generation, doubtlessly poses new challenges to improvement programs. It is estimated that by 2025 average productivity in Brazil will rise from the present 79 t/ha to $90-100$ t/ha, with a change in the varietal profile, which should be directed to biomass production, for power co-generation, and for the production of ethanol from cellulose.

To obtain this new biotype, it is essential to know the taxonomic and evolutionary relationships of sugarcane, as well as the genetic improvement background of current varieties.

\section{GENETIC RESOURCES IN SUGARCANE}

Sugarcane is a grammineae of the Poaceae family, Andropogoneae tribe, and Saccharum genus, characterized by a high level of ploidia, and 
frequent aneuploidia. Sugarcane cultivars feature alogamy and high heterozygosity, generally not tolerating endogamy (HOARAU et al., 2007).

The Saccharum genus encompasses six species: S. officinarum, S. robustum, S. spontaneum, S. barberi, S. sinense, and S. edule. S. officinarum clones $(2 \mathrm{n}=80)$, the domesticated species, are also known as noble canes for their sweet taste. $S$. robustum $(2 \mathrm{n}=60-80)$ and $S$. spontaneum (2n $=40-128)$ are considered wild species. $S$. barberi $(2 \mathrm{n}=81-124)$ and $S$. sinense $(2 \mathrm{n}=111-120)$ are known respectively as sugarcanes from China and India, having contributed with few genes to present cultivars. Most likely these two species derived from natural hybridizations between $S$. officinarum and $S$. spontaneum. S. edule $(2 \mathrm{n}=60,70,80)$. It is considered an ornamental species cultivated in gardens in New Guinea and the Fiji Islands, without having contributed to modern cultivars (DANIELS et al., 1975).

The six Saccharum species with the genera Erianthus, Miscanthus, Narenga, and Sclerostachya compose an intercrossing group known as the "Saccharum Complex" (DANIELS et al., 1975), which represents the genetic variability for sugarcane improvement.

ROACH (1989) divided sugarcane improvement in three stages, from its outset in 1890. The first stage comprised crossing and clone selection of $S$. officinarum, which were used in the first sugar plants worldwide. Though these clones had good industrial qualities (high saccharose content, low fiber, and low impurities), they did not have vigor nor long life, and were very susceptible to pests and diseases. The second stage involved the development of interspecific hybrids between $S$. officinarum and other species, mainly S. spontaneum, followed by successive retrocrossings of interspecific hybrids with noble cane (Saccharum officinarum), to recover the saccharose content existing in the recurring ancestor, in a process named nobilization (BREMER, 1961). This stage represented the quantum leap in the genetic improvement of sugarcane, providing the sugaralcohol industry with a new performance in raw material, reflected in highly productive varieties, with good tillering capacity, proper stalk diameter, more resistant to pathogens and pests, and resprouting capacity after several cuts (ROACH, 1972; JANOO et al., 1999). Adoption of planned hybridizations resulted in more than doubling the potential yield of sugarcane varieties. One important variety produced in this stage was POJ2878, obtained by Dutch improvers in 1921 in Java, which became a very important ancestor, present in the majority of modern varieties genealogy in all countries that cultivate sugarcane. The third stage involved exploring the hybrids developed in the second phase as parents. However, due to the success obtained in stage II, reflected on the gains in recurring selection progenies, little effort was made to use other accesses of $S$. spontaneum and $S$. officinarum, or other existing clones within the "Saccharum Complex". As a consequence, the improvement of sugarcane is based on a few parental ancestors, which were widely intercrossed, producing hundreds of varieties, determining a narrow genetic base for culture. For this reason, gains obtained in improvement have become ever more limited, yet those resulting from genotype versus environment having become more expressive than genetic gains per se. For this reason, Brazilian improvement programs have been trying to develop regional varieties, adapted to specific environments. It is estimated that only 13 clones were used in the initial crossings, of which eight $S$. officinarum, two S. spontaneum, one probably natural hybrid between $S$. spontaneum and $S$. officinarum, and two clones of $S$. sinense (available at: <http://www.ars-grin.gov/npgs/cgc_reports/ sugar.html>.

Analyses based on DNA polymorphisms have revealed a wide genetic variability between accesses of $S$. officinarum coming from different origin centers (AITKEN et al., 2006). On the other hand, Saccharum spontaneum is the species presenting the widest variability within the "Saccharum Complex", with chromosomes number varying from $2 n=40$ to 128 , yet existing euploid and aneuploid forms. Ample variations in morphologic and physiologic characteristics have been observed in collections of $S$. spontaneum 
(MARY et al., 2006). Therefore, it is a fact that the genetic variability found in the genes set used by sugarcane improvers is little representative of the genetic variability existing in both the genus and the "Saccharum Complex". According to the division proposed by ROACH (1989), it is timely to include a fourth stage in the sugarcane genetic improvement, focused on the implementation of a genetic base enlargement program, to explore new sources of germplasm to develop varieties having the characteristics for biomass production. Along this line, varieties with high potential yield, displaying characteristics adequate for mechanized planting and harvesting, well adapted to the Brazilian "cerrado", as well as an improved energy balance at lower production costs should represent the portfolio of sugarcane varieties in the next two decades.

Within this context, sugarcane genetic improvement will require new sources of germplasm. In Brazil, the largest germplasm collection (and also the best represented) is located in Camamu, Bahia, and was owned by Copersucar, today under the management of Centro de Tecnologia Canavieira-CTC (Sugarcane Technology Center). This collection has about 4,500 accesses, including many representative of the "Saccharum Complex". However, its use is restricted to CTC. The other three existing collections belong to the sugarcane improvement programs of Rede Interuniversitária de Desenvolvimento do Setor Sucroalcooleiro Ridesa (Inter-University Network for the SugarAlcohol Industry), Instituto Agronômico de Campinas - IAC (Campinas Institute of Agronomy), and Canavialis - Monsanto. IAC's and Ridesa's collections are essentially represented by crossing parents, with few representatives of the "Saccharum Complex". Canavialis is setting up a replica of the USDA collection, however, like Copersucar/CTC, its use will be restricted. Therefore, it is essential for Brazil to endeavor establishing a sugarcane germplasm collection for public use, representative of the genetic diversity existing in the "Saccharum Complex". Hence, usage and introduction accesses policies for the "Saccharum Complex" have to be implemented. Priority should be given to those species having highest potential use in improvement, such as S. officinarum and S. spontaneum. Nevertheless, the genera Erianthus and Miscanthus are adapted to unfavorable environments, being Miscanthus adapted to cold, and Erianthus to drought, both having high yield for biomass, hence very interesting for bioenergy.

Germplasm characterization studies carried out in other countries have identified very promising accesses for $S$. spontaneum, S. officinarum, Erianthus, and Miscanthus to be used in genetic improvement, most of these accesses not being represented in the collections existing in Brazil.

In view of the aforesaid, we consider that the sugarcane germplasm issue is strategic, and a national emergency - issue in Brazil. The unavailability of access to new sources of genes by Brazilian improvement programs may cause a loss of competitiveness to the country in the generation of varieties with adequate characteristics for producing ethanol, as other countries have initiated programs focused on energy cane, exploring species and genera in the "Saccharum Complex".

Currently, the implementation of a public collection depends almost exclusively on the accessibility to international sugarcane collections, as for the time being the largest collections existing in Brazil are not open to international exchange. The two world leading Saccharum collections, known as World Collection for their importance, are: the USA collection, kept in Canal Point (Miami), represented by 2,426 clones of various Saccharum species, in addition to 95 clones de Mischantus, and the one in India, kept in two places, Kannur, with 1,381 accesses to the Saccharum genus, and Coimbatore with 825 items of the "Saccharum Complex". The one in India is considered better than its American counterpart, as it is well characterized. However, access to these materials is very difficult. The Miami one is easier to access, though many materials have been lost due to storms and difficulties in preserving accesses representing species and genera, which are not well adapted to the American weather conditions. Other important collections are those in Australia, South Africa, and Cuba. The Cuban collection is well represented by 
species of the "Saccharum Complex", due to several collection expeditions in the places of origin over the past 20 years.

However, due to the importance of sugarcane in Brazil, the introduction of germplasm should be made with caution, as there is a risk of introducing, together with the genotypes of interest, a new disease or pest, jeopardizing the national sugarcane culture. Therefore, we think that a public sugarcane germplasm collection should be implemented, made up by representatives of the existing collections in Brazil. Importing germplasms would be solely for those materials not represented in the existing collections. Thus, it is necessary to implement policies on usage and introduction of accesses for sugarcane. Furthermore, all introduction, exchange, and quarantine procedures should follow the international guidelines described by FAO (FAO, IBPGR Technical Guidelines for the Safe Movement of Yam Germplasm), otherwise the national security of Brazilian cane culture might be jeopardized.

\section{CONTRIBUTION OF SUGARCANE GERMPLASM IN CULTIVARS DEVELOPMENT FOR BIOMASS PRODUCTION}

Sugarcane programs have always prioritized saccharose content as the main feature to be maximized; consequently, a considerable part of the genes contributing to increase fiber content were gradually eliminated from the current varieties' genetic background. Fiber and Pol characters hold a negative correlation, i.e., the direction given to the biotype of the sugar-alcohol cane then, where saccharose content was a priority, gradually reduced the fiber content of the varieties so far selected. Also, there was no interest in obtaining varieties with high fiber content, as such characteristic, when present in high concentration in a genotype, makes it difficult to extract juice industrially. For this reason, a new pool of genes must be explored to ensure success in developing varieties for bioenergy generation.

For such purpose, it is essential that Brazilian improvement programs strive to enlarge the genetic base of this culture by means of genetic introgression programs, mainly exploring accesses of $S$. spontaneum and representatives of the Erianthus and Miscanthus genera.

Studies like these have been conducted in countries interested in sugarcane for bioenergy, such as in Barbados (West Indies Central Sugar), Australia, China, and the USA (Louisiana State University Agricultural Center and Texas \& AM University).

Characters like vigor, which contribute to biomass and fiber production, may be found in accesses of Saccharum spontaneum and related genera, like Miscanthus. Miscanthus species have been used mostly by European forage improvement programs as an energy culture (CLIFTONBROWN et al., 2008). Special attention should be paid to $S$. spontaneum clones, which are well adapted to Brazilian conditions, and offer high potential for producing biomass.

According to WANG et al. (2008), sugarcane genotypes having closer relationship to $S$. spontaneum than to current sugarcane cultivars present potential for power generation. Genotypes derived from $S$. spontaneum with favorable characteristics, such as adaptation to adverse conditions and displaying string growth on resprouting, may present competitive costs in comparison to other prospective species/genera.

The Mauritius improvement program (Sugarcane Breeding Program from Mauritius Sugar Industry Research Institute - MSIRI) has invested in genetic base enlargement programs by interspecific hybridizations between $S$. spontaneum and $S$. officinarum clones. In these hybridizations, the major difficulty has been the asynchronous flowering of $S$. officinarum and S. spontaneum. To circumvent this problem, induced flowering in photoperiod chambers has been used, enabling the breed of commercial clones of $S$. officinarum with $S$. spontaneum, to introgress the wild genoma in the commercial background, a strategy that has been making it possible to increase fiber content with acceptable saccharose levels and other commercial attributes. Though negative correlations have been found between Pol and fiber, it was possible to select families with 
positive correlations between these characters, allowing the selection of clones FS1 that combine desirable Pol\%Cane and fiber\%Cane characters,

\section{REFERENCES}

AITKEN, K. S.; LI, J. C.; JACKSON, P.; PIPERIDIS, G.; MEINTYRE, C. L. AFLP analysis of genetic diversity within Saccharum and comparison with sugarcane cultivars. Australian Journal of Agricultural Research. 57 (11), 1167-1184, 2006.

ALBERT-THENET J. R. 2003. Fuel cane for the production of electricity in Barbados. Proceedings of the Barbados society of technologists in agriculture.

BREMER, G. 1961. Problems in breeding and cytology of sugarcane. I. A short history of sugarcane breeding the original forms of Saccharum. Euphytica, 10:59-78.

CLIFTON-BROWN, J.; CHIANG, Y-C.; HODKINSON, T. R. Miscanthus: genetic resources and breeding potential to enhance bioenergy production. In: Genetic improvement of bioenergy crops. Springer Nova York: Vermerris, W. Ed., 2008. 423 p.

DANIELS, J.; SMITH, P.; PATON, N.; WILLIAMS, C. A. 1975. The origin of the genus Saccharum. Sugarcane breeding newsletter, 36:24-39.

HOARAU, J. Y.; SOUZA, G.; D'HONT, A.; MENOSSI, M.; PINTO, L. R.; SOUZA, A. P.; GRIVET, L.; MENCK, C. F. M.; ULIAN, E. C.; VINCENTZ, M. 2007. Sugarcane, a tropical crop with a highly complex genome. In: MOROT-GAUDRY, J. F.; LEA, P.; BRIAT, J. F. (Ed). Functional Plant Genomics. Science publ., p. 481- 499. JANOO, N.; GRIVET, L.; SEGUIN, M.; PAULET, F.; DOMAINGUE, R.; RAO, P. S.; DOOKIUN, A.; D'HONT, A.; of interest for both the production of improved varieties and parents to be used in improvement programs (RAO, 2007).

GLASZMANN, J. C. 1999. Molecular investigation of genetic base of sugarcane cultivars. Theor App Genet, 99:171-184.

LEAL, M. R. L. V. Personal comunication, 2008.

MARY, S.; NAIR, N. V.; PANKAJ KUMAR CHATURVEDI, SELVI, A. 2006. Analysis of genetic diversity among Saccharum spontaneum $\mathrm{L}$. from four geographical regions of India, using molecular markers. Genetic Resources and Crop Evolution, 53: 1221-1231.

PIPERIDIS, G.; CHRISTOPHER, M. J.; CARROLL, B. J.; BERDING, N.; D`HONT, A. (2000) Molecular contribution to selection of intergeneric hybrids between sugarcane and the wild species Erianthus arundinaceus. Genome, 43: 1033-1037.

RAO, S. EnergyCane: the Barbados experience. In: VIII Workshop Cana Energia: Cana - Diretrizes de Políticas Públicas para a Indústria Canavieira do Estado de São Paulo. 2007. Available at: <http://www.apta.sp.gov.br/ cana/ver_work.php?work_id=51>.

ROACH, B. T. 1972. Nobilization sugarcane. Proc. Int. Soc. Sugarcane Technol. 14: 206-216.

WANG, L. P.; JACKSON, P. A.; LU, X.; FAN, Y. H.; FOREMAN, J. W.; CHEN, X. K.; DENG, H. H.; FU, C.; MA, L.; AITKEN, S. (2008). Evaluation of sugarcane x Saccharum spontaneum progeny for biomass composition and yield components. Crop Science, 48: 951:991. 
